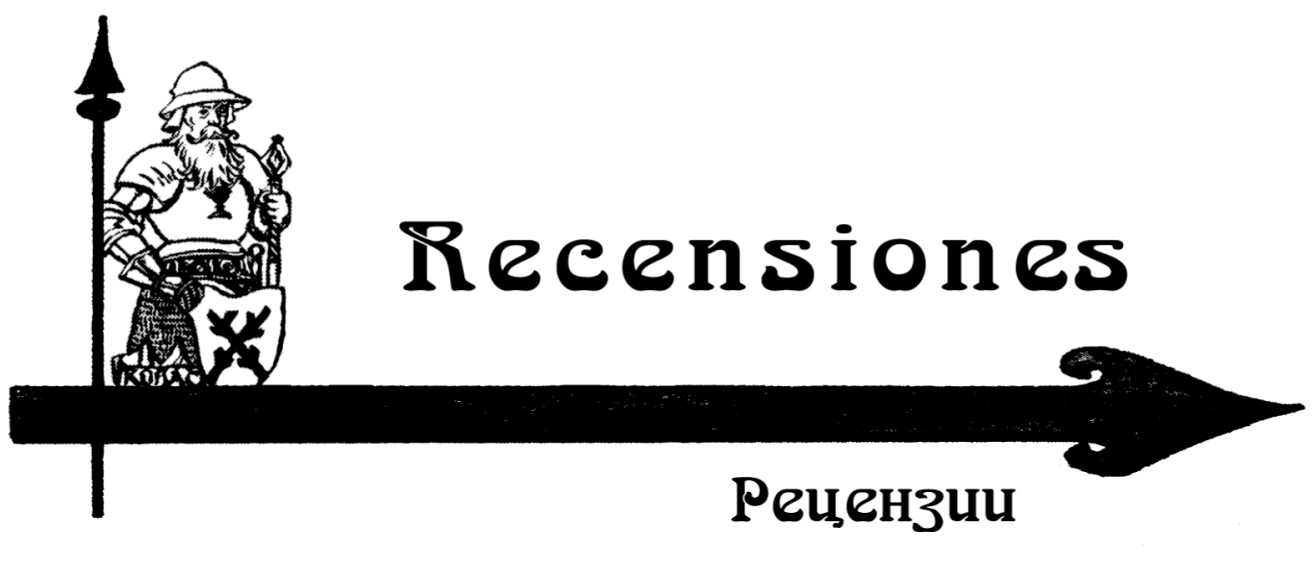

УДК 94 (47); ББК 63.3(2); DOI https://doi.org/10.21638/spbu19.2018.210

Ch. J. Halperin

\title{
THE EARLY MODERN MUSCOVITE STATE RECONSIDERED
}

Mikhail Krom's new monograph, Rozhdenie gosudarstva. Moskovskaya Rus'XV-XVI vekov', is an ambitious attempt to reconceptualize the problem of the origins of the Muscovite state and to contest the paradigm of Russian exceptionalism, that Muscovy fundamentally differed from contemporary European countries and essentially diverged from the European model of early-modern statehood. Krom makes the case that Muscovy did have a state by tracing the presence of several identifying characteristics of early modern European statehood in Muscovy and further argues that Muscovy fits the European model, although, like all European countries, it had its peculiarities. Although written for a popular audience, Rozhdenie gosudarstva. Moskovskaya Rus'XV-XVI vekov should stimulate lively discussion among specialists in Muscovite history.

${ }^{1}$ Krom M. M. Rozhdenie gosudarstva. Moskovskaya Rus' XV-XVI vekov [The Birth of the State. Muscovite Russia in the $15^{\text {th }}$ and $16^{\text {th }}$ centuries]. Moscow: «Novoe literaturnoe obozrenie» Publ., 2018. 256 p. (Illustrations. Bibliography. ISBN 978-5-4448-0769-9. — Page references will be supplied in the text in parentheses.)

(C) Charles J. Halperin, 2018 


\section{INTRODUCTION}

Scholarship on Muscovite history during the $15^{\text {th }}$ to $17^{\text {th }}$ centuries has never attained a consensus on the nature of the Muscovite state or its similarity or dissimilarity to contemporary European states. This is usually formulated as the issue of Russian exceptionalism, but without exception, it has never questioned the existence of a Muscovite «state» at that time. The titles of articles and books on the subject proceed from that premise. For example, Aleksandr Filyushkin wrote an article on «The Role of the "Taking of Kazan" in the Establishment of Russian Statehood»" Anna Khoroshkevich wrote an article on «The History of Statehood in Public Polemics during the Period of Centralization» and a short monograph on The Symbols of Russian Statehood ${ }^{3}$. Any discussion of «church-state» relations, such as Vyacheslav Shaposhnik's monograph, Church-State Relations in Russia from the 1530s to the 1580s, presupposes that the «state» existed, else it could not have had «relations» with the (Russian Orthodox) Church ${ }^{4}$. Aleksandr Yanov's monograph, Russia: The Roots of Tragedy in 1462-1584. Notes on the Nature and Origin of Russian Statehood deals with a change in the nature of the Russian state (to which I will return), which had to exist for it to change ${ }^{5}$. It is no coincidence that at a Round Table at the 2007 convention of the American Association for the Advancement of Slavic Studies in New Orleans on November 16, 2007 entitled «Should Historians Call Russia a State?», Daniel Rowland alone answered in the negative ${ }^{6}$.

The question of Russian exceptionalism is always with us. The dominant opinion, both in Russia and the West, remains that Russia differed - and, indeed, still differs from Europe. There is, however, a recent trend among some, especially US specialists, to emphasize the commonalities between Europe and Muscovy during the early modern period $^{7}$. This revisionist opinion dominated a more recent panel of the renamed Association for Slavic, East European and Eurasian Studies on «Muscovy in Comparative Perspective», on November 18, 2016. At this panel Krom gave a paper on «The Muscovite Tsardom as an Early Modern State», which similarly concluded that Muscovy was comparable, but not

${ }^{2}$ Filyushkin A. I. Rol' «Kazanskogo vzyatiya» v stanovlenii russkoy gosudarstvennosti // Nestor. Istoriko-kul'turnye issledovaniya. Almanac. Issue 1. Voronezh, 1993. P. 46-56.

${ }^{3}$ Khoroshkevich A. L. 1) Istoriya gosudarstvennosti v publitsistike vremeni tsentralizatsii // Obshchestvo i gosudarstvo feodal'noy Rossii. Sbornik statey, posvyashchenniy 70-letiyu akademika L’va Vladimirovicha Cherepnina. Moscow: «Nauka» Publ., 1975. P. 114-124; 2) Simvoly russkoy gosudarstvennosti. Moscow: Moscow State University Press, 1993.

${ }^{4}$ Shaposhnik $V$. $V$. Tserkovno-gosudarstvennye otnosheniya v Rossii v 30-80-e gody XVI veka. $2^{\text {nd }}$ exp. red. St. Petersburg: St. Petersburg State University Press, 2006.

${ }^{5}$ Yanov A. L. Rossiya: U istokov tragedii 1462-1584. Zametki o prirode i proiskhozhdenii russkoy gosudarstvennosti. Moscow: «Progress-Traditsiya» Publ., 2001. - Metaphorically Yanov goes even further, describing the oprichnina not as a «state within a state» but as a «state over the state» (P. 208-213).

${ }^{6}$ My memory of this round table is minimal. I believe that Nancy Shields Kollmann and Valerie Kivelson argued in favor of the existence of a state, but I cannot recall the positions of John Le Donne and Sergio Nun-Ingerflom.

${ }^{7}$ For bibliography on the hypertrophic and collegial, consensual interpretations of the Muscovite state see: Kivelson $V$. Muscovite «Citizenship»: Rights without Freedom // Journal of Modern History. No. 74. 2002. P. 465-489. See also: Halperin C. J. The Nature of the Muscovite State During the Reign of Ivan IV: The Tyranny of Concepts // Bushkovitch, Paul (ed.). The State in Early Modern Russia: New Approaches. Bloomington: Slavica Publishers, Inc., 2019. P. 1-26, forthcoming. 
identical, to early modern European states, an issue on which all the presenters agreed ${ }^{8}$. I will return to Krom's argument below.

By definition the two issues of the existence and nature of the Muscovite state on the one hand, and whether that state resembled or differed from contemporary European states, on the other, are inextricably linked. It would be difficult to deal on one without touching on the other. Soviet scholarship had no problem with either issue because Marxism dictated that as a class society Muscovy had to have a state for the ruling class to oppress the peasants and artisans, and that Muscovy resembled other «feudal» states in early modern Europe and was unlike the few «bourgeois» European states, largely limited to England, The Netherlands, and northern Italy. Post-1991 Krom is the first historian in Russia to my knowledge to ask if $15^{\text {th }}$ - and $16^{\text {th }}$-century Muscovy was a «state» and the first to pursue the similarities and differences between Muscovy and contemporary European states systematically.

\section{The BirTh Of THE StaTe}

Rozhdenie gosudarstva. Moskovskaya Rus'XV-XVI vekov consists of «From the Author», a substitute for an introduction, ten chapters, a substitute for a conclusion, acknowledgments, and a «Short Bibliography».

In «Ot avtora» (From the Author) (p. 7-8) Krom describes his work as unusual in that he has written a popular work (nauchno-populyarnaya kniga) ${ }^{9}$ before publishing a scholarly monograph on the same theme. He explains this atypical sequence by the fact that it would take many years and perhaps a collective to produce a monograph on the birth of the Muscovite state $^{10}$. Besides, this popular genre has the virtue of compelling the author to express complex ideas in accessible language. Because this is a popular book, with a press run of 5,000 copies, footnotes contain only commentary, not references. For the same reason Krom supplies modern Russian translations of nearly all his quotations from Muscovite original sources. Krom informs the reader that this book replaces the traditional narrative of warfare and political unification with a thematic examination of various aspects of domestic Muscovite history within a comparative framework.

In «Russkoe gosudarstvo XV-XVI vekov v zerkale Evropeyskogo opyta (Vmesto vvedeniya)» (The Russian State of the $15^{\text {th }}$ and $16^{\text {th }}$ centuries in the mirror of European experience (in place of an introduction) (p. 9-25) Krom identifies the two scholarly inspirations of his book, Max Weber's concept of an impersonal bureaucracy, replacing personal patrimonial relations, as the hallmark of modern states, and Joseph Strayer's pioneering study of the medieval origins of modern states, who included impersonal political institutions in his list of the characteristic attributes of the modern state. A modern state must have a stable territorial core, sovereign independence against foreign secular or ecclesiastical authority, must, following Joseph Schumpeter, shift from the ruler supporting himself from his domain to relying upon taxes, must command the loyalty of its residents above devotion to family, class, or region, and must be governed under state-wide laws ${ }^{11}$. Krom concedes that there are regional variants

\footnotetext{
${ }^{8}$ Donald Ostrowski and Daniel Rowland also presented papers at this panel.

${ }^{9}$ The book appeared in the series Chto takoe Rossiia (What is Russia).

${ }^{10}$ Or a single historian with the scholarly abilities and work capacity of Nancy Shields Kollmann, author of Kollmann N. S. The Russian Empire, 1450-1801. Oxford: Oxford University Press, 2017, to which I will return.

${ }^{11}$ Strayer J. R. On the Medieval Origins of the Modern State. Princeton: Princeton University Press, 1970.
} 
among the various early modern European states. They developed at different chronological paces; some did not undergo unification, and some had much lower levels of urbanization. Nevertheless, Krom insists upon the utility of a common model which also fits Muscovy. He also notes in passing recent attempts to expand the concept of early modern statehood beyond the boundaries of «Europe» to include the Ottoman Empire.

In Chapter 1, «Velikoe knyazhestvo Moskovskoe i ego sosedi v 1425 godu» (The Muscovite Grand Principality and its neighbors in 1425) (p. 27-43) Krom asserts that Muscovy in 1425 was not a state. Rather, it resembled European kingdoms or baronies. The Muscovite grand prince was still a servitor (ulusnik) of the Mongol khan of the Golden Horde (the Juchid ulus) and thus lacked sovereignty.

In Chapter 2, «Dinasticheskaya voyna 30-40-kh godov XV veka i rozhdenie "gospodarstva" $\mathrm{i}$ "gosudarstva"» (The dynastic war of the 1430s-1440s and the birth of the concepts of gospodarstvo and gosudarstvo) (p. 45-67). Krom suggests that the Muscovite Orthodox Church became autocephalous at this time is comparable to the «nationalization» of European churches, starting before but becoming much stronger during the Reformation. Krom observes that the new title of the Muscovite grand prince as gospodar' or gosudar' (sovereign) originated in the metropolitan's chancellery, that as result of dynastic war Muscovy was transformed into «monarchy with a tendency toward single-authority government (edinoderzhavie)», and that a government administration began to impose uniformity on judicial and financial terms on the entire Muscovite territory. The concept of autocracy (samoderzhavstvo) as sovereignty began to combine with «a conception of unlimited inherited authority».

Because the modern Russian word for state, gosudarstvo, derives from the word for «sovereign» (gosudar'), when gosudarstvo ceased being an attribute of rulership which might be translated as «realm» and acquired the meaning of «state», an abstraction separate from the person of the ruler figures prominently in any analysis of the origins of the Muscovite state.

In Chapter 3 «Ivan III: obretenie gosudarstvennogo suvereniteta» (Ivan III: the attainment of state sovereignty) (p. 69-93) Krom dates Muscovite sovereignty, a sine qua non of statehood, to the Stand on the Ugra River in 1480 that in retrospect terminated Tatar rule. He notes that urban republics in the early modern period almost universally failed to preserve their independence; the fate of Novgorod and Pskov is no surprise. The concept of a "composite monarchy» might have fit Ivan III's Muscovy briefly, but soon its component units lost their autonomy. Although Ivan III's irredentist foreign policy sought acquisition of the lands of Kievan Rus', Muscovy was not a national state but resembled the Habsburg and Ottoman Empires. Under Ivan III Muscovy began firmly defining its western (but not its eastern and southern steppe) boundaries by treaty. Codification of law was a common element of early modern state development, but because only one late manuscript of the 1497 Law Code (Sudebnik) survives, Krom infers that it was considered temporary and incomplete and was no more than a handbook of recommendations, not a compendium of mandatory prescriptions.

In Chapter 4 «Khan ili basilevs: bylo li Moskovskoe gosudarstvo naslednikom Zolotoy Ordy i Vizantii?» (Khan or basileus: Was the Muscovite state a successor of the Golden Horde or Byzantium?) (p. 95-105) Krom considers the superficial resemblance of some Muscovite institutions to those of the Horde insufficient to project Peter the Great's penchant for borrowing foreign institutions onto Muscovite rulers such as Ivan IV ${ }^{12}$. Muscovite princes ${ }^{12} \mathrm{As}$ a point of personal privilege I must comment that the Russian transliteration of my family name used in all my publications in Russian is, rightly or wrongly linguistically, "Gal'perin», not «Khal'perin». 
did not copy Mongol «procedures» (poryadki), although they did borrow fiscal and military institutions. However, those borrowed institutions underwent significant transformation. How could the recipient of the epistle to the Ugra River by Archbishop Vassian Rylo of Riazan', who claimed descent from Rome and considered Muscovy part of Europe, an Orthodox Christian ruler, copy the customs of Muslim Saray? Ironically, Byzantine influence increased after the fall of Byzantium, particularly on literature and bureaucratic paperwork (deloproizvodstvo). Muscovy borrowed Byzantine court ceremonial as well as a social institution, the bride-show, abandoned in Byzantium long before its conquest by the Ottomans. Krom concludes that the Muscovite state perceived itself as the heir neither of Constantinople nor Saray. Various German architectural or artistic influences did not determine the course of Muscovite development. As elsewhere Muscovy was an impressive amalgam of various influences structured on a local base.

Chapter 5, «Moskoviya v 1517 i 1526 godakh glazami avstriyskogo diplomata» (Muscovy in 1517 and 1526 through the eyes of an Austrian diplomat) (p. 107-119) addresses the influential account of Muscovy written by Baron Sigismund von Herberstein, «Notes Upon Muscovy». Herberstein exaggerated the power of the Muscovite ruler. Had he witnessed Henry VIII execute two of his wives and Sir Thomas More, Herberstein might have qualified his portrayal of Grand Prince Vasiliy III as exercising more sway over his subjects than any ruler in Europe. Herberstein visited the court of Suleiman the Magnificent but never compared Vasiliy III to the Ottoman Sultan; Muscovy may have been Orthodox, but it was still Christian. Other contemporary rulers were just as cruel or megalomaniacal as Vasiliy III but were not demonized as tyrants. The powers of those rulers were circumscribed by laws, customs, and institutions. In countries without strong parliamentary institutions, such monarchs encountered estate opposition. In Muscovy neither law nor institutions limited the ruler's authority, nor did the heterogeneous aristocracy. Ivan the Terrible's reign, Krom concludes, demonstrates that moral and religious constraints, such as the norms of Christian piety and remonstrances by the metropolitan of the Russian Orthodox Church, were inadequate to deter the ruler from «unlimited arbitrariness, despotism and oppression» (p. 119).

Krom begins Chapter 6, «Byurokratizatsiya upravleniya. Formirovanie prikazov» (Bureaucratization of administration. The Formation of bureaus) (p. 121-134) by noting that bureaucratization, so key to modern state development, elicited no comment from Herberstein, to whom government officials were unimportant. Krom dates the fundamental transformation of the central government apparatus to bureaus to the 1550s and 1560s. The combination of administrative and judicial authority in the hands of the same officials in Muscovy reproduced the pattern elsewhere in Europe at the time. Nor did Muscovy skip the paradox that all legal action was undertaken in the name of the ruler, even when in fact the bureaucracy initiated it.

Muscovite bureaucrats were as greedy and corrupt as those in Germany, but, unlike bureaucrats in Western and Central Europe, Muscovite officials (sanovniki) included no jurists, because there were no universities in which they could have studied law. As a result they learned their jobs on the job. England and Muscovy shared weak bureaucracies and perforce had to compensate by involving the population, especially the gentry, in administration.

Not surprisingly Chapter 7, «Tsarstvo Ivana Groznogo» (The Reign of Ivan the Terrible) (p. 137-175), is the longest in the book, even if it does, as Krom warns the reader, touch only a few episodes of that «stormy epoch» (burnaya epokha). Ivan IV's troubled childhood illustrated the weakness of the «young Russian (russkoe) state», because Muscovy had no legal 
norms for establishing a regency in Ivan IV's name. When in 1536 Muscovite boyars insisted to Lithuanian representatives that although Ivan was «young», his gosudarstvo was «mature», they meant that politically Ivan was mature and could not transfer his authority to his mother or a regent. The bureaucracy enabled the government to survive the crisis of Ivan IV's minority, although for a long time autocratic ideology did not even recognize the existence of the bureaucracy ${ }^{13}$. Popular assemblies were an integral part of the early modern state. The first Muscovite assembly (sobor) met in 1549, the so-called «Assembly of Reconciliation», after which the Royal Council passed the Law Code (Sudebnik) of 1550 whose aim was to ease the social tension between the capital elite (verkhushka) and the provincial gentry (dvoryanstvo). Krom disputes Klyuchevskiy's insistence that Muscovite assemblies did not arise out of conflicting social interests. Via consultation with various social groups, such as at the Assembly of 1566, the government expanded the public sphere of political activity (publichnaya politika), another attribute of the rising modern state, and a far cry from Vasiliy III's practice of meeting with two or three favorites in his bedchamber. The so-called «Chosen Council» (Izbrannaya rada) corresponded to the Privy Council (Blizhnyaya duma) but it is more important that its existence was not noted in any government documentation. The inability of historians to discover who compiled the Law Code of 1550 reflects the «weak bureaucratization of the administrative apparatus» in Russia at the time (p. 160). A radical reformer such as Peter the Great would have wiped out the archaic «Feeding» (kormlenie) system by which in lieu of salaries provincial governors and county administrators were sustained by the people they governed in goods and services, but in Ivan IV's Muscovy the «Feeding» system was only partially and gradually abolished.

According to Krom, the creation of the oprichnina (p. 168-175) was the result of the grant to Ivan IV by the Royal Council of dictatorial power, a clear sign that before 1565 no earlier tradition accorded him such freedom of action. The oprichnina was an openly despotic regime which relied upon mass terror. The unintended consequences of this policy of its «half-mad creator» (polubezumniy tvorets) included an increase in monastic land, further bureaucratization, and a weakening of Muscovy's army of gentry cavalry. Any evaluation of Ivan IV's reign would have to be negative; his absolute authority led to the destruction of the realm and the termination of the dynasty. Ironically, the first Muscovite tsar crowned «autocrat», Ivan IV's son Fedor Ivanovich, reigned but his brother-in-law Boris Godunov ruled, and fourteen years after Ivan IV's death, in 1598 Russia became an elective monarchy when an assembly of the land (zemskiy sobor) elected Godunov tsar, a form of government that Ivan IV hated.

According to Chapter 8, «Finansy Moskovskogo gosudarstva» (The Finances of the Muscovite State) (p. 177-188), while other early modern European states began generating revenue and expenditure books, the only available statistics for Muscovy originated in a work by a foreigner, Giles Fletcher's famous «Of the Russe Commonwealth». Unfortunately, Fletcher double-counted certain incomes and projected England's degree of fiscal centralization onto Muscovy, where in fact all revenues did not pass through the same central bureau, the Treasury. The Muscovite economy was «weakly monetized» (p. 182). The «Forbidden

${ }^{13}$ Readers will already be familiar with this line of analysis from Krom's magnum opus: Krom M. M. "Vdovstvuyushchee tsarstvo»: Politicheskiy krizis v Rossii 30-40-kh godov XVI veka. Moscow: «Novoe literaturnoe obozrenie» Publ., 2010, which I reviewed in: Kritika. No. 13. 2012. P. 469-475. 
Years» (Zapovednye leta) decrees during which peasant movement was forbidden were only declarative, because no administrative system existed to retrieve runaways, and only temporary, because in 1606 Godunov restored the St. George's Day provision ${ }^{14}$.

In Chapter 9, «Ideinye osnovy Moskovskogo gosudarstva» (Intellectual Foundations of the Muscovite State) (p. 191-217) Krom points out that all early modern states relied upon religion to legitimize their existence and policies. Ivan IV «attentively read the works of Iosif of Volokolamsk» (p. 196) but far exceeded his teacher in asserting the tsar's unlimited authority. In the 1550s Ivan listened to instructive sermons by the priest Sylvester and Metropolitan Makariy but he forgot all about their concern with justice and mercy when he launched his reign of terror and in response to Metropolitan Filipp's sermons he had him removed from office and murdered. However, the oprichnina was an «anomaly, violating the usual order or relations between the tsar and his subjects» (p. 197-198). The despot Ivan IV's «indomitable will» (derzhavnaya volya) (p. 198) could not be restrained by «soft» forms of control such as admonitions. Ivan IV's radical conclusions about royal power did not represent commonlyheld opinion in Muscovy. He thought that all his subjects were his «slaves», but in reality, the boyars were not «slaves» in the property sense and he did not treat them as «slaves», although boyars, like aristocrats serving Henry VIII, had no guarantees against disgrace, confiscation of property, and execution. Under Ivan IV even the formality of some sort of judicial process for boyars accused by the ruler was discarded. The demoralized and divided Russian gentry could not even muster the strength to protest Ivan IV's actions, although Swedish noble opposition against Erik XIV availed little until his brother Johann III took the lead. The «tyrant» Ivan IV did not live to see the response of his subjects to his monopolization of authority in the conditions imposed on the tsar in 1606. Muscovy did see the expression of the concept of the «general good» (obshchee delo chelovecheskoe or delo narodnoe) that no early modern state could do without, as formulated in the distinction between the tsar's and the land's affairs (tsarskoe i zemskoe delo), invoked quite widely by the middle of the century. Assemblies (sobory) sought to benefit the «general welfare» (obshchaya pol'za). Even during the oprichnina, the status of the «land's» affairs was elevated by describing them as «great» (velikie). By the beginning of the $17^{\text {th }}$ century the concept of the general good had been appropriated by the «assemblies of the land». Once again, the middle of $16^{\text {th }}$ century was the key transitional period in Muscovy's evolution from patrimonial to early modern state.

In Chapter 10, «"Nashe Moskovskoe gosudarstvo": rozhdenie gosudarstvennogo patriotizma» (Our Muscovite State: the birth of state patriotism) (p. 219-232) Krom concedes that although the word «patriotism» was unknown in Russia until the $18^{\text {th }}$ century, the «politically active layers» of the population (p. 219) were familiar with the sentiment, if previously attached to local polities such as cities or principalities. The concept of gosudarstvo could mean the territory of a ruler, his throne, his rule, and his authority, as well as the people under his rule, those «under my gosudarstvo»; regnal years also referenced gosudarstvo (the twentieth year of my gosudarstvo). Despite this semantic pluralism gosudarstvo remained an attribute of the ruler, although hints of its meaning as «state» can be found as early as the Law Code of 1497, which referred to a man living in «this state» (zdeshnee gosudarstvo). Expressions of state patriotism arose only during the Time of Troubles (Smutnoe vremya) when there was

${ }^{14}$ Peasants who had met all their obligations could move for one week before and one week after St. George's Day. This regulation originated in the 1497 Law Code and was retained, with some amendments, in the 1550 Law Code. 
no ruler. The transition from Ivan III's reference to «my gosudarstvo» to appeals to «our Muscovite gosudarstvo» during the Troubles could not be more explicit.

In his final segment, «Moskovskoe tsarstvo kak gosudarstvo rannego Novogo vremeni (Vmesto zaklyucheniya)» (The Muscovite tsardom as an early modern state (in place of a Conclusion) (p. 233-239) Krom concludes that although Ivan IV thought the sovereign was greater than the «state», his own policies facilitated the separation of the «state» from the «sovereign» both as a concept and in practice. As everywhere else, the state developed not only from the above but also from the below. A «civil society» (grazhdanskoe obshchestvo) arose precisely during Ivan IV's reign as the state mobilized gentry (dvoryanstvo) and merchants to perform administrative functions. Russia remained unique in Europe as the only state without jurists or Roman law. It was also exceptional economically, agrarian, insufficiently urbanized, under-monetized. Muscovy's most distinctive characteristic feature, noted by all foreign visitors, was the total subservience of the elite to the ruler, epitomized by their humiliating self-designation as «slaves» of the tsar. Slavery and patrimonial relations dominated society, the unique aspect (svoeobrazie) (p. 237) of Muscovy. Even if the process of depersonalization of the government via the bureaucracy was only in its incipient stages, all actions were attributed to the ruler. Such an archaic economy and archaic social relations did not preclude that Muscovy was still on its way to becoming modern and was already an early modern state.

Krom's bold analysis is expressed in extremely lucid and sometimes colorful, highly evocative language. Krom depicts Metropolitan Fotiy's travels between Lithuania and Muscovy to secure Vasiliy I's succession to the Muscovite throne as «shuttle diplomacy» (chelnochnaya diplomatiya) (p. 48). The bloody Muscovite dynastic war resembles a Shakespearean play (p. 55). Inability to deal with minor or incompetent rulers was the «Achilles heel» of autocratic monarchies (p. 143). "The autonomy of work of the administrative services did not let the ship of state sink despite the cruel oprichnina storm» (Avtonomiya raboty administrativnykh sluzhb ne pozvolila gosudarstvennomu korablyu poyti na dnu vo vremya zhestokoy orprichnoy buri) (p. 172-173).

Krom's prose is enhanced by ten surreal black-and-white drawings, one preceding each chapter, although I have not been able to decipher all of them, and much less ambiguously, by twenty glossy color illustrations on twenty-five unnumbered pages (some illustrations cover two pages) between pages 160 and 161, including several maps, miniatures from the «Illustrated Chronicle Compilation (Litsevoy letopisniy svod), gravures, Dmitriy Gerasimov's reconstructed bust of Ivan IV, manuscript folia, and the candlestick base with an etching of an oprichnik on a horse with a dog's head and broom on its neck. Unfortunately, Krom does not integrate these illustrations into his exposition. Because Krom's discussion of the oprichnina does not mention dogs' heads or brooms, the reader has to figure out the significance of that illustration without assistance from the author.

Mikhail Krom's Rozhdenie gosudarstva. Moskovskaya Rus'XV-XVI vekov is a major original contribution to Russian history masquerading, as it were, as a popular work. $\mathrm{He}$ is not the first historian to appreciate that state-formation was a process, not an event, but he is the first to apply that concept systematically to $15^{\text {th }}$ and $16^{\text {th }}$-century Muscovite history. He has rethought the narrative of Muscovite history and integrated a variety of domestic developments into a coherent revisionist argument. Nothing I have read in Russian on Ivan IV approaches the depth of comparative history that Krom has achieved. The centrality of the reign of Ivan IV in the transition from a patriarchal form 
of government to a modern state stands out. His analysis abounds in striking observations and comparisons, only a few of which have been cited above. This book should be read by all historians of Russian history, not just specialists in Muscovite history.

\section{COMMentary}

It would take a team of specialists months to respond to the plethora of issues that Krom raises in Rozhdenie gosudarstva. Moskovskaya Rus' $X V-X V I$ vekov. All of his conclusions merit serious consideration. The following comments are intended to facilitate further discussion of Krom's stimulating synthesis of two centuries of Muscovite history ${ }^{15}$.

Krom's presentation highlights the problem of distinguishing a «government» (pravitel'stvo) from a «state». Does any form of government which includes officials automatically constitute a «state»? How many attributes of statehood and to what degree are necessary to characterize a form of government as a «state» or as evolving toward a «state»? If a «state» must be sovereign, i.e. not answerable to an external polity, then is a decentralized state a «state»? Is a federal state one state or many? Perhaps the notion of a hierarchy of states would be more flexible. I happily leave such questions to political scientists.

On terminology, as far as I can tell Krom uses «russkoe (ethnic Russian) state» and «rossiyskoe (territorial, non-ethnic) state» indiscriminately. Krom does not apparently assign distinctive meanings to each term.

Krom occasionally refers to the Muscovite dvoryanstvo, by which from context he means the $16^{\text {th }}$-century gentry. As he knows far better than I do, dvoryanstvo became a generic term for the gentry only in the $17^{\text {th }}$ century. In the $16^{\text {th }}$ century it meant members of the royal Court or Household (Dvor), which included boyars, gentry, bureaucrats, and artisans. The $16^{\text {th }}$-century term for gentry was deti boyarskiye. This anachronistic use of the word dvoryanstvo was endemic in Soviet scholarship; it is disappointing that Krom has not corrected it, even in writing a popular work.

Krom's remarks in Chapter 3 on the anomalies of the Law Code of 1497 are intriguing, but I wonder if he has not taken sufficiently into account the fact that after 1550 its manuscripts were obsolete, so it might not be as significant as he thinks that only one survives.

Also, in Chapter 3 Krom makes a passing reference to Muscovy as not a «national state», but closer to the Habsburg and Ottoman Empires. Krom does not engage the concept of nation-state so often applied to early modern Europe in this book. In an article he assigns to the $16^{\text {th }}$ century the development of ethnic, Great Russian «nationality» (narodnost') in Muscovy, ethnic consolidation. Otherwise the patriotism displayed during the Time of Troubles could not have been present ${ }^{16}$. His article presented nationality development as an element of state formation. Krom does not explain his omission of this theme in Rozhdenie gosudarstva or his interpretive reversal.

Concerning Chapter 4 I do not know what Krom means by Mongol «procedures», although I infer that it is something other than the proposition that Muscovy was a successor

${ }^{15}$ Krom of course drew upon his numerous articles and monographs in writing Rozhdenie gosudarstva. Historians who wish to examine Krom's documentation can find the appropriate apparatus in those articles to compensate for the absence of reference footnotes here.

${ }^{16}$ Krom M. M. K voprosu o vremeni zarozhdeniya idey patriotizma v Rossii // Mirovospriyatie i samosoznanie russkogo obshchestva (XI-XX vv.). Sbornik statey. Moscow: Institute of Russian History Press, 1994. P. 17, 24-25. 
state of the Juchid ulus. After criticizing Donald Ostrowski for portraying Muscovite rulers anachronistically as predecessors of Peter the Great in borrowing foreign institutions, Krom admits that Muscovite did imitate Mongol military and fiscal institutions and diplomatic forms in their foreign relations with oriental states. However, he mentions other Muscovite institutions of Mongol origin only in different chapters, tarkhan tax immunities (p. 185), which he identifies as Mongol, and the postal system (yam) (p. 125), whose Mongol origin he fails to mention. Archbishop Vassian's attempt to delegitimize the Chinigissid clan fell on deaf ears at the Muscovite court and could hardly have inhibited Ivan III from respecting Chingissid khans or borrowing Mongol institutions.

In Chapter 7 on Ivan IV Krom estimates the number of oprichnina victims, based upon the synodical lists. at approximately 4,000; the greatest specialist on the synodical lists, Ruslan Skrynnikov, computed 3,300 victims. In Chapter 8 Krom claims that Ivan read the works of Iosif of Volokolamsk attentively. While I do not question the plausibility of this assertion, as far as I can tell Ivan IV nowhere quotes Iosif in his First Epistle to Kurbskiy, so I wonder on what evidence Krom derived this conclusion Krom seems to blame the influence of leading clerics such as Makariy and of the boyars, who donated land to monasteries for memorial prayers and took a proprietary interest in monasteries to which they were particularly attracted, for Ivan IV's failure until the very end of his reign to limit monastic acquisitions of land (p. 186). Krom omits Ivan IV's own penchant for donating land to monasteries.

Also in Chapter 7 in the passage about the «young» Ivan IV and the «mature» or «adult» Muscovite gosudarstvo, perhaps gosudarstvo references the abstraction of the state. Even if this interpretation is correct, it would be the exception that proves Krom's rule that in the $16^{\text {th }}$ century gosudarstvo rarely meant «state». In any event, Krom could have explicated directly an irony of $16^{\text {th }}$-century Muscovite thought which he deserves credit for discovering. However precocious, the concept of state found expression not in the modern Russian word that means «state», but in the word for «land» (zemlya) in the expression «the sovereign's and the land's affairs».

In discussing the significance of the development of assemblies (sobory) and the concept of the «general good» in Muscovy during Ivan IV's reign in Chapter 7 Krom does not repeat a very astute observation from one of his articles. If assemblies and the concept of the «general good» arose in Muscovy during the $16^{\text {th }}$ century, then it is one-sided to claim that the main consequence of Ivan IV's reign was his «assertion of unlimited autocracy (or absolutism)». The creation of assemblies and the formulation of the concept of the general welfare were just as significant in the long run as Ivan IV's extreme claims to authority ${ }^{17}$.

In his conclusion-substitute Krom describes Muscovy as the only Christian world state without credentialed jurists (p. 236). This may very well be technically true if we consider only the independent states of the time. It would not be true of the non-independent countries of Greece, Serbia and Bulgaria, then parts of the Ottoman Empire ${ }^{18}$.

That even during Ivan IV's reign all actions were committed in the tsar's name (p. 238) is correct, but by the 1570 s correspondence from bureaus no longer perpetuated the facade that

${ }^{17}$ Krom M. M. «Delo gosudarevo i zemskoe»: ponyatie obshchego blaga v politicheskom diskurse Rossii XVI veka // Sosloviya, instituty i gosudarstvennaya vlast' v Rossii (Srednie veka i rannee novoe vremya). Sbornik statey pamyati akademika L. V. Cherepnina. Moscow: «Languages of Slavic culture» Publ., 2010. P. 585.

${ }^{18}$ I cannot speak for Moldavia or Wallachia, Ottoman vassals and therefore not sovereign states. 
it came from the ruler. Instead, charters and instructions declared their origin in a bureau by name and referred to relations with other bureaus, a sign of advanced bureaucratization that Krom could have invoked.

Krom does not draw a distinction between the modern state versus the early modern state, although he clearly perceives early modern states as steps along the path to modern states. Despite his great familiarity with scholarship in Western languages on early modern Europe, he did not engage Jack Goldstone's assault on the concept of an «early modern period» of history. Goldstone argues that there is no such thing as modernization, ergo there is no such thing as the «modern», and therefore there can be no such thing as «early modern» history ${ }^{19}$.

Although Krom mentions contemporary empires, specifically Habsburg and Ottoman, he does not engage the problem of the relationship of empire to state. He seems to treat empires as a variety of state without implications for its domestic political structure. This is particularly surprising given the recent «Imperial turn» in Russian history, as evidenced by Kollmann's already cited recent survey, with enormous resonance for the study of Romanov, Soviet, and post-Soviet modern Russian history.

Krom is familiar with recent literature questioning or redefining the theory of absolutism. Elsewhere he acknowledged Nicholas Henshall's critique of absolutism and concluded that «It is already clear that 'absolutism' cannot serve as the conceptual frame of the all-European model of early modern state» ${ }^{20}$. Regardless, here he employs the terms «absolutism» and «absolute» superficially and not entirely consistently. He misses an opportunity to note that some studies of Europe posit that absolutism, regardless of its theory, always involved in practice the delegation of authority over central government functions to institutions and social classes ${ }^{21}$. Instead Krom attributes reliance on local gentry as volunteers in Muscovy and England to their undersized bureaucracies. Krom writes that the Ottoman Empire is still considered to belong to the early modern European model despite (my emphasis-CJH) the fact that the sultan claimed absolute authority in theory while the vizier ruled (p. 17-18), although European rulers claimed absolute authority too. Patriarchal patrimonial relations proved «fertile soil» for absolutism or even despotism in Muscovy, yet Ivan IV was the only despot. More moderate forms of despotism appeared in some German states, such as Brandenburg-Prussia and patrimonialism in Hesse (p. 25). Ivan III lacked the theoretical foundation for unlimited absolute authority, but exercised it anyway. Krom refers to one-man-rule, the concept of edinovlastie, one ruler only per country (p. 77), but does not correlate single-authority with autocracy or despotism.

Krom discusses the presence of the attributes of statehood in Muscovy and the articulation of the concept of statehood in Muscovy separately, which raises a fundamental issue. It would be perfectly defensible to argue that consciousness of statehood arose out of the presence

${ }^{19}$ Goldstone J. A. The Problem of the «Early Modern» World // Journal of the Economic and Social History of the Orient. No. 41 (3). 1998. P. 249-284.

${ }^{20}$ Krom M. M. Gosudarstvo rannego novogo vremeni: obshcheevropeyskaya model' i regional'nye razlichiya // Novaya i noveishaya istoriya. No. 4. 2016. P. 3-15, here 5, 6 (quotation). - He also discussed the concept of the fiscal-military state, not mentioned in Rozhdenie gosudarstva, arguing that it does not fit the Polish-Lithuanian Commonwealth or early Tudor-Stuart England.

${ }^{21}$ See n. 22 below. 
of state institutions. In short, attributes preceded theory. However, Strayer, after admitting that most definitions of states are not very satisfactory, wrote:

«A state exists chiefly in the hearts and minds of its people; if they do not believe it is there, no logical exercise will bring it to life. $<\ldots>$ The final, most important, and most nebulous $<\ldots>$ test [of statehood is] a shift in loyalty from family, local community, or religious organization to the state and the acquisition by the state of a moral authority to back up its institutional structure and its theoretical legal supremacy. At the end of the process, subjects accept the idea that the interests of the state must prevail, that the preservation of the state is the highest social good» ${ }^{22}$.

Krom concedes that his first solid evidence of statehood consciousness comes from the Time of Troubles. I wonder if the presence of some attributes of statehood in $16^{\text {th }}$ century Muscovy such as bureaucratization, by Krom's own evaluation «weak», qualifies Muscovy as a state in the absence of the articulated state loyalty that Strayer highlights.

Finally, the question of Russian exceptionalism needs to be addressed. Krom qualifies his conclusions in a way which cannot avoid diluting them. Krom proposes a model of early modern European history which admits of variation, so that all early modern European states do not need to be identical. In his American convention presentation, he identified the lack of abstract theory as the most significant difference between Muscovy and other European countries, but I did not find that contrast in Rozhdenie gosudarstva except concerning regencies. Here he emphasizes the lack of Roman law and jurists in Muscovy, but then demotes that contrast by assigning the most importance to the critical issue of relations between the ruler and the elite ${ }^{23}$. The absence of more than customary and religious restraints on Ivan IV's unlimited authority, whether we label that authority absolute, autocratic, despotic, or tyrannical, coupled with the servility of the Muscovite aristocracy, distinguished Muscovy from the other European countries who adhered to the early modern European model of statehood. The difficulty with this seemingly consistent exposition is that Krom insists that Ivan IV's treatment of the aristocracy, indeed even his definition of his unlimited authority, are exceptions to Muscovite history, atypical anomalies, and therefore unqualified to serve as defining characteristics of Muscovite history. At the same time he finds other European rulers, not just Henry VIII but also Erik XIV, acting almost as arbitrarily and violently as Ivan IV. Erik XIV was overthrown, Henry VIII, like Ivan IV, «got away with» his excesses. Therefore, Muscovy was like Europe in state development, except in several ways in which it was not. Ivan IV was like European rulers, except in a way in which he was not, except that some European rulers were qualitatively but not quantitatively similar. Krom sees Ivan IV and Muscovy as unique in Europe but still European.

It is not that simple. Krom correlates the development of absolute authority with patrimonial relations in Muscovy with the development of absolutism, even despotism, yet absolutism

${ }^{22}$ Strayer J. R. On the Medieval Origins of the Modern State. P. 5, 9.

${ }^{23}$ In this he diverges from what he rightly identifies as the most original and profound recent exploration of the nature of the Muscovite state: Kivelson $V$. Merciful Father, Impersonal State: Russian Autocracy in Comparative Perspective // Modern Asian Studies. No. 31 (3). 1997. P. 635-663, who sees cooperation with local elites as an integral aspect of centralization, not a variant (p. 636) which does not promote unlimited autocracy or despotism (p. 651). Kivelson contrasts Muscovy's facade, which lacked the discourse of rights and institutions (p. 663), with European practice, the main point of Krom's conference paper. 
certainly developed in England and France, where presumably societies were less «archaic» and patrimonial relations less pervasive. Krom insists that Muscovy also differed from Europe in its archaic economic and social relations. Elsewhere he emphasized that $16^{\text {th }}$ century Muscovite society, economy, and culture were medieval, unlike that of Western European countries during the Renaissance and Reformation. He chides historians who forget that contrast and thus misinterpret Vassian Patrikeev's views of monasticism in terms of Protestant Reformation advocacy of secularizing all ecclesiastical lands or attribute the motivation for Muscovy's entrance into the Livonian War to economic interests when Muscovy lacked a credible bourgeoisie with the ability to lobby the government on its behalf. In its retention of patrimonial relations longer than Western Europe, Muscovy resembled Northern, Central and Eastern Europe. No early modern European state was «typical $\rangle^{24}$. Muscovy still developed or was at least in the process of developing an early modern state that fell within the parameters of the European model. One does not have to be a Marxist who believes that the economic base determines the political superstructure to realize that Krom is proposing that the early modern state structure was independent of its economic and political base. Krom also runs the risk of comparing Muscovy to a model of early modern European statehood that carries the a-historical weakness of all Weberian ideal types: the full attributes of the model may never have appeared at the same time in the same country. That an early modern state could develop in a country without an early modern society or economy is simply too significant a premise to appear without elaboration.

The historiographic tradition further complicates the situation. The Russian exceptionalism school foregrounds precisely Russian agrarian and social «backwardness» (a word that Krom does not use) and the existence of a hypertrophic state, whose rulers were not constrained by constitutional limitations on their authority, as the defining difference between Russia and Europe, which prevented Russia from following the path that led to democracy (another concept that Krom does not engage). Krom's partial recognition of the validity of these contrasts, at least in the minds of adherents of the exceptionalist school, confirms their interpretation and contradicts Krom's argument that despite these differences, the incipient Muscovite state was still early modern European because of the heterogeneity of the model of early modern European state.

Yanov proposed a different solution to this conundrum. He argued that Muscovy was on the path to a modern European state, ultimately to democracy, before Ivan IV's reign. Ivan IV singlehandedly diverted Russia from that path and turned it into an oriental despotism. Krom sees Ivan IV's rule as an exception; after Ivan IV's death, Muscovy «returned» to the development of an early modern European state, whereas Yanov believes that Ivan IV set the pattern for all subsequent rulers in Moscow. Yanov's view of the consequences of Ivan IV's rule is shared one way or another by other historians such as Daniil Al', Boris Florya, and Maureen Perrie and Andrey Pavlov, who all agree that Ivan IV personally changed the course of Russian history away from the Western model and toward the oriental.

I would propose a slightly different evaluation of Ivan IV's place in Muscovite and $16^{\text {th }}$ century European history. Ivan IV was the exception in Muscovite history because he was

${ }^{24}$ Krom M. M. Rozhdenie gosudarstva Novogo vremeni v Rossii i v Evrope: Sravnitel'noistoricheskaya perspektiva // Trudy kafedry istorii Rossii s drevneishikh vremen do XX veka. Vol. I. St. Petersburg: St. Petersburg State University Press, 2006. P. 35. 
generally like his contemporary European rulers, who made the $16^{\text {th }}$ century exceptionally violent and whose personal deportment was just as arbitrary and cruel as Ivan IV's. This conception of Ivan IV and his reign in his own time does not prejudge the impact of Ivan IV's legacy on subsequent Muscovite and Russian history, which I leave open.

The conceptual breadth of Mikhail Krom's Rozhdenie gosudarstva. Moskovskaya Rus'XV$X V I$ vekov requires readers to confront such fundamental issues in Muscovite and European history, which redounds to its credit. This book should serve as the starting point for much new research on Muscovite history during the $15^{\text {th }}$ and $16^{\text {th }}$ centuries.

Информация о статье

Автор: Гальперин, Чарльз - доктор истории, внештатный историк, Университет Индианы, Блумингтон, США, chalperi@iu.edu; OrcID 0000-0002-6667-0555

Заголовок: The Early Modern Muscovite state reconsidered [Московия как раннемодерное государство: переосмысление]

Резюме: Статья посвящена анализу новой монографии Михаила Крома «Рождение государства: Московская Русь XV - начала XVI веков», где переосмысляется проблема происхождения и сущности Москвии - вопросы, которые ни кем из историков ранее не ставились под сомнение. М. Кром оспаривает парадигму русской исключительности, утверждая, что к середине XVI в. Московия уже обладала достаточным количеством характеристик, свойственных государствам ранней модерной Европы, и тоже может называться ранним модерным европейским государством. Проведя тщательный сравнительный анализ, историк приходит в выводу, что несмотря на то что Московия отличалась от других европейских государств неограниченной властью правителя и раболепием элиты, европейская модель может быть к ней применима.

Ключевые слова: Московия, государство, бюрократия, суверенитет, всеобщее благосостояние, Иван IV

Литература, использованная в статье:

Goldstone, Jack A. The Problem of the «Early Modern» World // Journal of the Economic and Social History of the Orient. No. 41 (3). 1998. Pp. 249-284.

Halperin, Charles $J$. The Nature of the Muscovite State During the Reign of Ivan IV: The Tyranny of Concepts // Bushkovitch, Paul (ed.). The State in Early Modern Russia: New Approaches. Bloomington: Slavica Publishers, Inc., 2018. Pp. 1-26.

Kivelson, Valerie. Merciful Father, Impersonal State: Russian Autocracy in Comparative Perspective // Modern Asian Studies. No. 31 (3). 1997. Pp. 635-663.

Kivelson, Valerie. Muscovite «Citizenship»: Rights without Freedom // Journal of Modern History. No. 74. 2002. Pp. 465-489.

Kollmann, Nancy Shields. The Russian Empire, 1450-1801. Oxford: Oxford University Press, 2017. 512 p. Strayer, Joseph R. On the Medieval Origins of the Modern State. Princeton: Princeton University Press, 1970. $114 \mathrm{p}$.

Кром, Михаил Маркович. «Вдовствующее царство»: Политический кризис в России 30-40-х годов XVI века. Москва: Новое литературное обозрение, 2010. 833 с. (Historia Rossica).

Кром, Михаил Маркович. «Дело государево и земское»: понятие общего блага в политическом дискурсе России XVI века // Сословия, институты и государственная власть в России (Средние века и раннее новое время): Сборник статей памяти академика Л. В. Черепнина. Москва: «Языки славянской культуры», 2010. 585 с.

Кром, Михаил Маркович. Государство раннего нового времени: общеевропейская модель и региональные различия // Новая и новейшая история. 2016. №. 4. С. 3-15.

Кром, Михаил Маркович. К вопросу о времени зарождения идей патриотизма в России // Мировосприятие и самосознание русского общества (XI-XX вв.): Сборник статей. Москва: Институт Российской истории, 1994. С. 17-25.

Кром, Михаил Маркович. Рождение государства Нового времени в России и в Европе: сравнительноисторическая перспектива // Труды кафедры истории России с древнейших времен до XX века. Вып. I. Санкт-Петербург: Издательство Санкт-Петербургского государственного университета, 2006. С. 17-36. 
Кром, Михаил Маркович. Рождение государства: Московская Русь XV-XVI веков. Москва: Новое литературное обозрение, 2018.256 с.

Филюшкин, Александр Ильич. Роль «Казанского взятия» в становлении русской государственности // Нестор: Историко-культурные исследования: Альманах. Выпуск 1. Воронеж, 1993. С. 46-56.

Хорошкевич, Анна Леонидовна. История государственности в публицистике времени централизации // Общество и государство феодальной России: Сборник статей, посвященный 70-летию академика Льва Владимировича Черепнина. Москва: Наука, 1975. С. 114-124.

Хорошкевич, Анна Леонидовна. Символы русской государственности. Москва: Издательство Московского государственного университета, 1993. $96 \mathrm{c}$.

Шапошник, Вячеслав Валентинович. Церковно-государственные отношения в России 30-80-е годы XVI века. 2-е изд. Санкт-Петербург: Издательство Санкт-Петербургского государственного университета, 2006. $568 \mathrm{c.}$

Янов, Александр Львович. Россия: У истоков трагедии 1462-1584: Заметки о природе и происхождении русской государственности. Москва: «Прогресс-Традиция», 2001. 559 с.

Informatoin about the article

Author: Halperin, Charles J. - PhD, Research Associate, Russian and East European, Indiana University, Bloomington, Unated states of America, chalperi@iu.edu, OrcID 0000-0002-6667-0555

Title: The Early Modern Muscovite state reconsidered

Summary: Mikhail Krom's new monograph «Rozhdenie gosudarstva. Moskovskaia Rus' XV - XVI vekov» reconceptualizes the problem of the origins and nature of the Muscovite state, whose existence almost no previous historian had questioned. He disputes the paradigm of Russian exceptionalism, arguing that by the middle of the sixteenth century Muscovy possessed a sufficient number of the qualifying characteristics of an early modern European state to be called an early modern European state. Although Muscovy differed from other early modern European states in the unlimited authority of the ruler and the servility of the elite, the European model still applies. Krom raises numerous conceptual and substantive questions about Muscovy within a rigorously comparative framework. Although Krom presents his book as a popularization, it should be read by all specialists as well.

Keywords: Muscovy, state, bureaucracy, sovereignty, general welfare, Ivan IV

\section{References:}

Filyushkin, Aleksandr Ilyich. Rol' «Kazanskogo vzyatiya» v stanovlenii russkoy gosudarstvennosti [The Role of the «Taking of Kazan» in the Establishment of Russian Statehood], in Nestor. Istoriko-kul turnye issledovaniya. Almanac. Issue 1. Voronezh, 1993. Pp. 46-56. (in Russian).

Goldstone, Jack A. The Problem of the «Early Modern» World, in Journal of the Economic and Social History of the Orient. No. 41 (3). 1998. Pp. 249-284.

Halperin, Charles J. The Nature of the Muscovite State During the Reign of Ivan IV: The Tyranny of Concepts, in Bushkovitch, Paul (ed.). The State in Early Modern Russia: New Approaches. Bloomington: Slavica Publishers, Inc., 2018. Pp. 1-26.

Khoroshkevich, Anna Leonidovna. Istoriya gosudarstvennosti v publitsistike vremeni tsentralizatsii [The History of Statehood in Public Polemics during the Period of Centralization], in Obshchestvo i gosudarstvo feodal'noy Rossii. Sbornik statey, posvyashchenniy 70-letiyu akademika L'va Vladimirovicha Cherepnina. Moscow: «Nauka» Publ., 1975. Pp. 114-124. (in Russian).

Khoroshkevich, Anna Leonidovna. Simvoly russkoy gosudarstvennosti [The Symbols of Russian Statehood]. Moscow: Moscow State University Press, 1993. 96 p. (in Russian).

Kivelson, Valerie. Muscovite «Citizenship»: Rights without Freedom, in Journal of Modern History. No. 74. 2002. Pp. 465-489.

Kivelson, Valerie. Merciful Father, Impersonal State: Russian Autocracy in Comparative Perspective, in Modern Asian Studies. No. 31 (3). 1997. Pp. 635-663.

Kollmann, Nancy Shields. The Russian Empire, 1450-1801. Oxford: Oxford University Press, 2017. 512 p. Krom, Mikhail Markovich. «Delo gosudarevo i zemskoe»: ponyatie obshchego blaga v politicheskom diskurse Rossii XVI veka [«Business of the Sovereign and the Land»: The Concept of the Common Good in Russian Political Discourse of the $16^{\text {th }}$ century], in Sosloviya, instituty i gosudarstvennaya vlast'v Rossii (Srednie veka i rannee novoe vremya). Sbornik statey pamyati akademika L. V. Cherepnina. Moscow: «Languages of Slavic culture» Publ., 2010. 585 p. (in Russian). 
Krom, Mikhail Markovich. Gosudarstvo rannego novogo vremeni: obshcheevropeyskaya model' i regional'nye razlichiya [State of the Early Modern Period: European Model and Regional Differences], in Novaya i noveishaya istoriya. 2016. No. 4. Pp. 3-15. (in Russian).

Krom, Mikhail Markovich. K voprosu o vremeni zarozhdeniya idey patriotizma v Rossii [To the Question about the Time of the Patriotism Idea Origin in Russia], in Mirovospriyatie i samosoznanie russkogo obshchestva (XI-XX vv.). Sbornik statey. Moscow: Institute of Russian History Press, 1994. Pp. 17, 24-25. (in Russian).

Krom, Mikhail Markovich. Rozhdenie gosudarstva. Moskovskaya Rus'XV-XVI vekov [The Birth of the State. Muscovite Russia in the $15^{\text {th }}$ and $16^{\text {th }}$ centuries]. Moscow: «Novoe literaturnoe obozrenie» Publ., 2018. 256 p. (in Russian).

Krom, Mikhail Markovich. Rozhdenie gosudarstva Novogo vremeni v Rossii i v Evrope: Sravnitel'noistoricheskaya perspektiva [The Birth of the State in the Modern Period in Russia and in Europe: A Comparative Historical Perspective], in Trudy kafedry istorii Rossii s drevneishikh vremen do XX veka. Vol. I. St. Petersburg: St. Petersburg State University Press, 2006. P. 27-36. (in Russian).

Krom, Mikhail Markovich. «Vdovstvuyushchee tsarstvo»: Politicheskiy krizis v Rossii 30-40-kh godov XVI veka [«Widowed Kingdom»: The Political Crisis in Russia during the 30s and 40s of the $16^{\text {th }}$ century]. Moscow: «Novoe literaturnoe obozrenie» Publ., 2010. 833 p. (in Russian).

Shaposhnik, Vyacheslav Valentinovich. Tserkovno-gosudarstvennye otnosheniya v Rossii v 30-80-e gody XVI veka [Church-State Relations in Russia from the 1530s to the 1580s]. $2^{\text {nd }}$ exp. red. St. Petersburg: St. Petersburg State University Press, 2006. 568 p. (in Russian).

Strayer, Joseph R. On the Medieval Origins of the Modern State. Princeton: Princeton University Press, 1970. 114 p.

Yanov, Aleksandr L'vovich. Rossiya: U istokov tragedii 1462-1584. Zametki o prirode i proiskhozhdenii russkoy gosudarstvennosti [Russia: The Roots of Tragedy in 1462-1584. Notes on the Nature and Origin of Russian Statehood]. Moscow: «Progress-Traditsiya» Publ., 2001. 559 p. (in Russian). 